\title{
POZITÍV PSZICHOLÓGIA: AZ ELMÉLETTŐL A GYAKORLATIG
}

\author{
NAGY HENRIETT ${ }^{1}$ \\ ${ }^{1}$ ELTE Eötvös Loránd Tudományegyetem, Pszichológiai Intézet \\ E-mail: nagy.henriett@ppk.elte.hu
}

Beérkezett: 2019. október 1. - Elfogadva: 2019. október 17.

\begin{abstract}
A pozitív pszichológia, amely Seligman és Csíkszentmihályi (2000) szerint a jóllét megismerésére törekvô tudományos áramlat, az utóbbi két évtizedben világszerte nagy népszerüségre tett szert. A hazai pozitív pszichológia témájú kutatásokat elsóként, Oláh Attila szerkesztésében a Magyar Pszichológiai Szemle 2012-ben megjelent különszáma mutatta be. Jelen tanulmány kisérletet tesz arra, hogy áttekintse a pozití pszichológiához kötődố, a fentiekben említett különszám megjelenése óta született legfontosabb eredményeket (pl. az egységesítô jóllétmodellek; a személyiség és a jóllét komplex összefüggései; a flow pszichogenetikai és neurobiológiai magyarázatai; egészséges pozitív érzelmek és optimális érzelmi egyensúly). Másik célkitúzésünk az irányzat jövôjének alakulását befolyásoló újabb kritikai észrevételek megfogalmazása, elsôsorban a pozitív pszichológiai intervenciók hatékonyságához kapcsolódóan.
\end{abstract}

Kulcsszavak: pozitív pszichológia, jóllét, pozitív érzelmek, pozitív pszichológiai intervenciók

A pozitív pszichológia alapjait Martin Seligman és Csíkszentmihályi Mihály fektették le az American Psychologist (Amerikai Pszichológus címú folyóirat) 2000-ben megjelent, pozitív pszichológia témájú különszámához írt elôszavukban. E tanulmány megjelenése óta a pozitív pszichológia irányzata gyors fejlôdést mutatott, és világszerte nagy népszerúségre tett szert. A hazai pozitív pszichológia témájú kutatásokat elsôként Oláh Attila szerkesztésében a Magyar Pszichológiai Szemle 2012-ben megjelent különszáma mutatta be. Oláh e kötet bevezetô cikkében a pozitív pszichológia elsô 10 évének legfontosabb eredményeirôl (pl. az erôsségek leltárának kidolgozása, a pozitív érzelmek elméletének megalkotása, a mentális egészség tünettanának és kétdimenziós modelljének kimunkálása, az élményfokozó stratégiák azonosítása) és hiányosságairól írt. Legerôsebb kritikai észrevételként egy átfogó elmélet hiányát fogalmazta meg, hang- 
súlyozva, hogy a pozitív pszichológia irodalma gyakran használ metaforikus fogalmakat (pl. virágzás), ugyanakkor figyelmen kívül hagyja a tudományos konstruktumokkal kapcsolatban elvárt precíz definiáltság kritériumát. Oláh e bevezetô tanulmány zárásaként megfogalmazta azt a célkitúzést, hogy „a pozitív pszichológia a jelenlegi szénakazal állapotából, egy olyan összeszedett állapotba kerüljön, amelyben megszületik egy, a pszichológiatudomány klasszikus irányzataival is ringbe szállni képes, gazdag empirikus eredményeket integráló pozitív pszichológiai teória” $(2012,10)$. Jelen kötet, amely Oláh Attila 70. születésnapjának tiszteletére íródott, szintén ehhez az általános célkitûzéshez kíván hozzájárulni.

A kötet bevezetố tanulmánya kísérletet tesz arra, hogy röviden áttekintse a pozitív pszichológiához kötôdô, a fentiekben említett különszám megjelenése óta született legfontosabb eredményeket, és újabb kritikai észrevételeket fogalmaz meg, amelyek az irányzat jövőjének alakulását befolyásolhatják. Azt gondoljuk, hogy ezen a területen továbbra is kihívás a szerteágazó empirikus eredmények egységes elméletté integrálása, és ugyanilyen fontos szempont ennek a tudásnak az eredményes gyakorlattá formálása is.

\section{EGYSÉGESÍTŐ JÓLLÉTMODELLEK}

A jólléttel kapcsolatban a pozitív pszichológia hagyományosan azt hangsúlyozta, hogy a jóllétnek számos jól elkülönülố aspektusa különböztethetô meg, úgymint (1) szubjektív jóllét (a pozitív érzelmi állapotok gyakori jelenléte és a negatív érzelmek relatív hiánya, valamint egy élettel való általános elégedettségérzet, Diener, 1984), (2) pszichológiai jóllét (önelfogadás, személyes növekedés, életcélok jelenléte, másokkal való pozitív kapcsolatok, környezet feletti uralom, autonómia, Ryff, 1989), (3) szociális jóllét (szociális elfogadás, szociális kiteljesedés, szociális integráció, szociális koherencia, szociális hozzájárulás, Keyes, 1998) és (4) spirituális jóllét (az élet olyan alapvetô kérdéseihez való pozitív viszonyulás, mint a halandóság problémája, az élet értelmének és céljának kérdése, illetve a magasabb rendû erôk létezésének kérdésköre, Compton, Smith, Comis és Qualls, 1996). Újabban azonban néhány szerzô mégis egy egységesítô jóllétmodell lehetôsége mellett érvel (Oláh, 2012, Huppert és So, 2013). 2013-ban Huppert és So a virágzás új elméleti modelljét javasolták, amelyet a mentális betegségeket kategorizáló rendszerek (A Mentális Zavarok Diagnosztikai és Statisztikai Kézikönyve, DSM; Betegségek Nemzetközi Osztályozása, ICD-10) figyelembevételével alakítottak ki. A virágzó személy 10 pozitív jellemzőjét a major depressziós epizód, a depresszív epizód és a generalizált szorongásos zavar terminológiáját alapul véve ezek ellentétpárjaként határozták meg. A virágzás diagnózisához a modell szerint az alábbi jellemzôk közül 8 jelenléte szükséges: pozitív érzelmek, kompetencia, érzelmi stabilitás, elkötelezôdés, értelem, optimizmus, pozitív kapcsolatok, reziliencia, önértékelés és vitalitás. Oláh Attila (2012) egy hasonló elméleti keretben, szintén abból kiindulva, hogy bár a különbözó jóllétösszetevôk ugyan eltérést mutathatnak, ugyanakkor közülük az összes lényeges a mentális egészség alakulása szempontjából, a globális jóllét fogalmát vezette be azt feltételezve, hogy a jóllétnek megállapítható egy globális szintje, amelynek alakulására a jóllét egyes dimenzióiban (érzelmi, pszichológiai, szociális és spirituális) lejátszódó történések gyakorolnak hatást. 


\section{A SZEMÉLYISÉG ÉS A JÓLLÉT KOMPLEX ÖSSZEFÜGGÉSEI}

A pozitív pszichológiai kutatások hatására, a jóllét területén jelentkezô egyéni különbségek magyarázatával kapcsolatban számos különbözô pszichológiai elmélet született (ezek közül a legjelentôsebbek a genetikai vagy személyi prediszpozíciós elméletek, és a folyamat- vagy tevékenységelméletek, további modellek bemutatását lásd Nagy, 2019). Korábban a genetikai vagy személyi prediszpozíciós elméletek elsôsorban azt hangsúlyozták, hogy a jóllétnek jelentôs személyiségbeli és genetikai meghatározottsága van. Az újabb kutatások ezen a területen arra vállalkoznak, hogy pontosabban tisztázzák, melyek azok a folyamatok, amelyek ezekért az összefüggésekért felelősek (Ryff, 2014; Soto, 2015; Nagy és Gyurkovics, 2016). Ezek a kutatások rávilágítottak arra, hogy a személyiség és a jóllét összefüggéseivel kapcsolatban nemcsak azt fontos megvizsgálni, hogy mely személyiségváltozók lényegesek a jóllét alakulása szempontjából, hanem azt is, hogy egy-egy személyiségvonás közvetlen hatást gyakorol-e a jóllétre, vagy más változók közvetítik a hatását. További kihívás tisztázni, hogy a személyiség és a jóllét között tapasztalt összefüggések mennyiben általánosíthatók a különbözô kultúrákra. Meg kell továbbá jegyezni, hogy a témában végzett korábbi kutatások többsége keresztmetszeti elrendezésû volt, ami nem tette lehetôvé az okság irányával kapcsolatos következtetések levonását. Az újabb kutatások között már szerepelnek longitudinális elrendezésû́ kutatások is (pl. Soto, 2015), amelyek a személyiség és a jóllét kölcsönös egymásra hatását valószerúsítik. Soto (2015) vizsgálatának eredményei például azt mutatják, hogy azok a résztvevôk, akik az elsố mérés alkalmával extravertáltak, barátságosak és érzelmileg stabilak voltak, növekedést mutattak a szubjektív jóllét területén a második mérés időpontjában. Másrészrôl azok, akik eredetileg magasabb jólléttel voltak jellemezhetôk, idôvel következetesen barátságosabbá, lelkiismeretesebbé, érzelmileg stabilabbá és extravertáltabbá váltak.

\section{A FLOW PSZICHOGENETIKAI ÉS NEUROBIOLÓGIAI MAGYARÁZATAI}

A folyamat- vagy tevékenységelméletek abból indulnak ki, hogy maguk a kellemes tevékenységek teremtik meg a jóllétet (Csíkszentmihályi, 1975), vagy éppen azt a folyamatot hangsúlyozták, ahogyan a célok követése hozzájárul a jóllétszint emelkedéséhez (Snyder, 1994; Emmons, 1996). Újabban néhány kutató biológiai (pszichogenetikai és neurobiológiai) oldalról közelíti meg a flow fogalmát. Az áramlatélmény átélésével kapcsolatos genetikai összefüggésekre Mosing és munkatársai (2012) vizsgálata hívta fel a figyelmet, melyben 444 svéd ikerpár vett részt. Az eredmények szerint a flow átélésére mutatkozó hajlam mérsékelten örökletes vonásnak tekinthetô. Késóbb Gyurkovics és munkatársainak (2016) kutatása arra mutatott rá, hogy a flow átélésére való hajlam a D2 dopaminreceptort kódoló gén egyik polimorfizmusához kötôdik, mely a striatrális D2 receptor múködésére van hatással. A neurobiológiai kutatások egyrészt abból indultak ki, hogy az áramlatélmény lényeges komponense az élményt kísérô optimális fiziológiai aktiváltság, másrészt az áramlatélmény alatt megfigyelhetô kérgi aktivitásszint-csökkenést hangsúlyozták. Peifer (2012) a flow és a kortizolszint összefüggését elemzó vizsgálatában azt találta, hogy egy bizonyos pontig kapcsolat áll fenn a kortizolszint és az áramlatélmény megjelenési valószínúsége között, ám egy bizonyos 
optimális ponton túl a kapcsolat negatívba fordul át. Ugyanez a kutatócsoport egy késôbbi kutatásában (Peifer, Schulz, Schächinger, Baumann és Antoni, 2014) hasonló, fordított U alakú összefüggést talált a flow átélésének valószínúsége és a szimpatikus aktiváció mutatója (alacsony frekvenciájú szívritmus-variabilitás) között. Ezek az eredmények azt sugallják, hogy az áramlatélmény megjelenése mérsékelt HPA-tengely-aktiváció és mérsékelt szimpatikus aktiváció mellett a legvalószínúbb, vagyis egy „optimális stressz-szint” esetén. A flow biológiai magyarázatával kapcsolatban a másik kiindulópontot a Dietrich által 2004-ben megfogalmazott ún. tranziens hipofrontalitás hipotézis képezi. Eszerint az áramlatélmény során a prefrontális kéreg aktivitása átmenetileg csökkenést mutat, ami azzal a következménnyel jár, hogy a magasan begyakorolt készségek a prefrontális régióhoz kötôdó explicit információfeldolgozó rendszerek beleszólása nélkül képesek érvényre jutni a viselkedésben. A hipotézis szerint a frontális „leszabályozódás” egyedül a figyelmi múködéseket nem érinti a homloklebenyi funkciók közül. Lényegében arról van szó, hogy az áramlatélmény során a prefrontális lebeny aktivációjának átmeneti csökkenése az éppen végzett feladat szempontjából irreleváns folyamatok leszabályozódásához vezet. Ez a zavaró tényezók kiiktatását jelenti, miközben fókuszált figyelem fordítódik az aktuális cselekvésre (Peifer, 2012). Az Oláh Attila által vezetett kutatócsoport (Soltész, Magyaródi, Mózes, Nagy és Oláh, 2012; Oláh és Nagy, 2014) számítógépes játék alkalmazásával indukált flow esetén EEG-mérésekkel erósítette meg a tranziens hipofrontalitás hipotézisét. Ulrich és munkatársai (2014) pedig MRI-vizsgálat alkalmazásával mutattak rá arra, hogy az áramlatélmény alatti átmeneti frontális leszabályozódás specifikusan a mediális prefrontális kéreghez kötődik, vagyis éppen ahhoz a területhez, amelyhez olyan szelffel kapcsolatos folyamatok kötốdnek, mint az éntudatosság vagy a szelfinvolvált érzelmek. Sôt, a flow-hoz kapcsolódó legújabb kutatások rámutattak arra, hogy társas helyzetekben a legintenzívebb a flow-élmény, vagyis akkor, amikor a személy interakciós helyzetben fókuszál a kihívást jelentô tevékenységre (Magyaródi és Oláh, 2017).

\section{EGÉSZSÉGES POZITÍV ÉRZELMEK ÉS OPTIMÁLIS ÉRZELMI EGYENSÚLY}

A pozitív pszichológia elméleti hátterének megalapozása szempontjából kiemelt jelentôségúek azok az érzelmekkel kapcsolatos tudományos kutatások, amelyek felhívták a figyelmet a pozitív érzelmek lelki egészségben betöltött lényeges szerepére. Fredrickson $(1998,2001)$ kutatásai rámutattak arra, hogy a pozitív érzelmekhez ugyanúgy társíthatók evolúciós elônyök, mint a negatív érzelmekhez. Illetve, hogy a pozitív érzelmek nem pusztán jelzôi, hanem aktív építôi is a személyes erôforrásoknak, és ezen keresztül a testi-lelki jóllét megalapozóinak tekinthetôk. Fredrickson és munkacsoportja a pozitív érzelmek közül a szeretetet tanulmányozta a legbehatóbban. A 2013-ban megjelent Love 2.0 címú könyvében Fredrickson azt állítja, hogy a szeretet egészséget teremt, illetve hogy mindenki képes olyan potenciál kifejlesztésére önmagában, amelynek segítségével alkalmassá válhat a szeretet minél gyakoribb hétköznapi átélésére. Fredrickson szerint a szeretet lényegében a pozitivitásrezonancia mikropillanata, vagyis egy apró pillanat, amikor tökéletes szinkronitás alakul ki két, egymás jóllétével törôdô ember biokémiája és viselkedése között. Fredrickson (2013) kutatásai rámutattak arra, 
hogy a vagális tónus és a pozitivitásrezonancia között lényeges összefüggések fedezhetôk fel. A kutatások egyrészt igazolták, hogy a vagális tónus ${ }^{1}$ alapján elốrejelezhetô az emberek napi szeretetélménye, másrészt rámutattak arra, hogy amennyiben a résztvevôket (pl. loving-kindness meditációval ${ }^{2}$ ) megtanítjuk arra, hogy többször éljenek át szeretetet, akkor ez emelni fogja a vagális tónusukat, ami pedig egyértelmú mutatója a jobb testi-lelki egészségi állapotnak.

Az újabb kutatások azonban a túlzó pozitivitás jelenségére is figyelmet fordítanak, és azt hangsúlyozzák, hogy a pozitív érzelmek átélése nem tekinthetô mindig kívánatos, alkalmazkodást szolgáló jellemzóként. Gruber és Purcell (2015) például hat szempontot javasolnak, amelyek mentén a pozitív érzelmekkel kapcsolatos problémás reakciók leírhatók: (1) ha a pozitív érzelmi válasz eltúlzóan intenzív; (2) ha nem illeszkedik a helyzethez, amelyben jelentkezik; (3) ha egy túlságosan szelffókuszú pozitív érzelem (pl. büszkeség) nehezíti, hogy a személy kapcsolódjon másokhoz; (4) ha a személy nem képes kontrollálni a pozitív érzéseit; (5) ha a pozitív és a negatív érzések közötti váltás váratlan és túl intenzív; (6) ha a személy túl nagy jelentôséget tulajdonít annak, hogy küzdjön a boldogságáért. Ebból következik, hogy a pozitív pszichológiai intervenciók célja nem általánosságban a pozitív érzelmek elômozdítása, hanem az egészséges pozitív érzelmek promóciója és az optimális érzelmi egyensúly beállítása.

\section{A POZITÍV PSZICHOLÓGIA ALKALMAZÁSI LEHETŐSÉGEI: POZITÍV INTERVENCIÓK}

A hétköznapi emberek és a pszichológusok közül is sokan szkeptikusak azzal kapcsolatban, hogy a jóllét szintje tartósan javítható. Idesorolhatók például a genetikailag meghatározott boldogságalapszintet feltételezô elképzelések (Diener, Suh, Lucas és Smith, 1999) vagy a jóllét örökletességére irányuló iker-, illetve adoptációkutatások eredményei (pl. Lykken és Tellegen, 1996; Tellegen és mtsai, 1988). Ezek az elméleti feltételezések és kutatási adatok lényegében azt sugallják, hogy bár a jóllétszint átmenetileg változhat, a személyek végül visszatérnek a rájuk jellemzô, genetikailag meghatározott boldogságalapszintre. Szintén kétségeket támaszthatnak a jóllét tartós növelésével kapcsolatban azok a kutatások, amelyek a boldogságszintet nagymértékben meghatározó személyiségvonások (neuroticizmus és extroverzió) hosszú távú stabilitását igazolták (Costa és McCrae, 1988). A pozitív pszichológusok közül azonban sokan (pl. Lyubomirsky, 2008) amellett érvelnek, hogy a pozitív élmények tudatos szabályozásán keresztül lehetséges a jóllét tartós növelése. A továbbiakban röviden áttekintjük a pozitív pszichológiai intervenciók hatékonyságával kapcsolatban rendelkezésre álló kutatási eredményeket, és hangsúlyozzuk az ezekkel kapcsolatban felmerülô kritikai szempontokat, végül útmutatásokat fogalmazunk meg a jövóbeli kutatások számára.

Sin és Lyubomirsky (2009) meghatározása szerint pozitív pszichológiai intervenciók alatt olyan önsegítô gyakorlatokat, csoportos tréningeket és egyéni terápiákat értünk

1 A nervus vaguson, a szívhez futó paraszimpatikus idegrostokon érkezó idegi aktivitás foka, a paraszimpatikus kisülések időegység alatti értéke.

2 A loving-kindness meditáció egy buddhista eredetú meditáció, amely az elfogadás, a szeretet és a gyengédség érzéseire fókuszál (Salzberg, 2011). 
(pl. Jóllét Terápia - Well-Being Therapy [WBT], Fava és Ruini, 2003; Pozitív Pszichoterápia, Seligman, Rashid és Parks, 2006), amelyek elsôsorban a pozitív érzelmek, kogníciók és viselkedések előmozdítását célozzák meg, nem pedig egy tünet, probléma vagy betegség megszüntetésére irányulnak. További kritérium, hogy ezeket az intervenciókat a pozitív pszichológia elméleti hagyományához kapcsolódóan dolgozták ki. Napjainkig a pozitív pszichológia kutatási eredményeit nagyrészt önsegítô könyvek foglalják össze, és az érdeklôdő személyek fôként önállóan gyakorolják az irányzat által javasolt pozitív aktivitásokat. A terápia keretében történô alkalmazás egyelőre kevésbé elterjedt, mint az önsegítô jelleggel történô gyakorlás vagy az intervenciós programok. Duckworth, Steen és Seligman (2005) kvalitatív elemzése alapján a szakirodalomban 100 fölötti a javasolt pozitív aktivitások száma. Ezek közül azonban csupán néhány stratégiára vonatkozólag rendelkezünk szigorú empirikus elemzésen alapuló hatásvizsgálattal. Ilyen például a három áldás gyakorlat ( ${ }^{3}$ l. Emmons és McCullough, 2003; Lyubomirsky, Sheldon és Schkade, 2005; Seligman, Steen, Park és Peterson, 2005) a személyes erôsségek használata ${ }^{4}$ (pl. Seligman, Steen, Park és Peterson, 2005) a savoring (az élet élvezete, pl. Jose, Lim és Bryant, 2012; Seligman, Rashid és Parks, 2006) vagy az aktív-konstruktív válaszadás ${ }^{6}$ (pl. Seligman, Rashid és Parks, 2006; Gable, Reis, Impett és Asher, 2004). ${ }^{7}$

A pozitív pszichológiai intervenciók fejlesztése, kutatása és alkalmazása napjainkig még gyerekcipóben járó, kidolgozás alatt álló terület. A vizsgált intervenciók nagy része olyan önsegítô gyakorlat vagy csoportos tréning, ahol a beavatkozás idôtartama tipikusan 1 nap és két hét közötti, és eddig kevés kutatás tesztelte a pozitív pszichológiai intervenciók hosszabb távú eredményességét, vagyis azt a kérdést, hogy a program során megszerzett erôforrások tartósan megmaradnak-e. Ráadásul a hosszú távú eredményességgel kapcsolatban gyakran ellentmondásos eredmények születtek. Például, Seligman és munkatársai (2005) kutatása rámutatott arra, hogy a köszönôlátogatás ugyan az intervenció után közvetlenül növeli a boldogságszintet, de ez a hatás 3 hónap múlva elmúlik. Vagy a három áldás gyakorlattal kapcsolatban Gander, Proyer, Ruch és Wyss (2013) azt találták, hogy a gyakorlat a depresszív tünetekre csak akkor hat, ha a résztvevôk 1 hétig gyakorolják a módszert, a két hétig gyakorlóknál ez a hatás már nem mutatkozik meg. Sốt, Sin, Della Porta és Lyubomirsky (2011) szerint a hálalevél írása még csökkentheti is a program elôtti jóllétszintet a mérsékelten vagy közepesen depressziós személyeknél.

Tipikus instrukció: Egy héten át lefekvés elôtt szánj 10 percet arra, hogy átgondold és leírd, hogy milyen 3 jó dolog történt veled aznap.

$4 \quad$ Fedezzék fel és használják új módokon a személyes erôsségeiket.

5 Az alábbi savoringstratégiák alkalmazása a mindennapokban: az örömteli élmények megosztása másokkal, emlékek építése, öngratuláció, összehasonlítás, szenzoros-perceptuális élesítés, abszorpció, viselkedéses kifejezés, idôi tudatosság, a hála átélése, az ünneprontó stratégiák kiiktatása.

6 Az ön feladata a következô hétre: gondosan figyeljen, amikor valaki arról számol be, hogy valami jó dolog történt vele. Igyekezzen aktív és konstruktív választ adni! Kérje meg az illetôt, hogy mesélje el az eseményt, minél hosszabban mesél, annál jobb. Szánjon sok idôt a válaszra reagálásra.

7 Témához kapcsolódó magyar nyelvú szakirodalom a további tájékozódás érdekében: Nagy, 2019. 
A pozitív pszichológiai intervenciók általános hatékonyságát vizsgáló elsô, 51 tanulmányra épülô metaelemzés eredménye szerint a pozitív pszichológiai intervenciók hatékonyak a jóllétnövelésében és a depresszív tünetek enyhítésében is, és ezek a hatások közepes mértékúek ( $r=0,29$ a jóllét, illetve $r=-0,31$ a depresszió esetében) (Sin és Lyubomirsky, 2009). Egy újabb kutatás (Bolier és mtsai, 2013) szigorúbb beválasztási kritériumokat alkalmazott, és kizárólagosan csak azoknak a randomizált, kontrollált kísérleteknek a metaelemzését végezte el, amelyek közvetlenül kötôdnek a pozitív pszichológia irányzatához. ${ }^{8}$ Összesen 40 tanulmányt vontak be, és az elemzés 6139 résztvevó adataira épült. A pozitív pszichológiai intervenciók hatásosságát a szubjektív jóllét, a pszichológiai jóllét és a depresszió vonatkozásában vizsgálták. Az eredmények az intervenciók alacsony-közepes mértékú hatékonyságát erôsítették meg ( $r=0,34$ a szubjektív jóllét, $r=0,20$ a pszichológiai jóllét és $r=-0,23$ a depresszió esetében). Ez a metaelemzés abban is különbözött az elôzôtôl, hogy már nemcsak a közvetlenül az intervenció végén mért értékeket vette figyelembe, hanem a 3-6 hónapos utánkövetésre vonatkozó eredményeket is. Ezek az adatok még mindig szignifikáns, de már alacsonyabb mértékú hatékonyságot jeleztek. A témában végzett frissebb metaelemzések (Weiss, Westerhof és Bohlmeijer, 2016) a fentiekkel egybehangzóan alátámasztották, hogy a pozitív pszichológiai intervenciók klinikai és nem klinikai mintán egyaránt hatékonyan növelik a jóllét szintjét, és a hatásméretek az alacsonytól a mérsékeltig terjednek. Legújabban a kutatások fókuszába a pozitív pszichológiai intervenciók hatékonyságát befolyásoló tényezôk feltárása került, ezek közül is a személyaktivitás-illeszkedés kérdéskör kapja a legtöbb figyelmet. Számos kutatás vizsgálta, hogy vajon a személyiségjellemzók meghatározók-e abból a szempontból, hogy kinél melyik pozitív pszichológiai intervenció lesz a legeredményesebb (pl. Lyubomirsky, King és Diener, 2005; Schuller, 2012). Ezek a kutatások tipikusan egy vagy két intervenciós stratégia elemzésére vállalkoztak, és egy bizonyos személyiségvonás összefüggésében elemezték az adott intervenció eredményességét. Schuller (2012) kutatásai például igazolták, hogy az introvertált és extrovertált személyek eltérô módon profitálnak a vizsgált specifikus pozitív intervenciókból. Az elemzések azt mutatták, hogy az extrovertált személyek többet profitáltak a köszönôlátogatás és a savoringgyakorlatokból, az introvertáltak pedig az aktív-konstruktív válaszadás, a személyes erôsségek és a három áldás gyakorlatok esetén mutattak jelentôsebb javulást. Továbbá az eredmények azt is jelezték, hogy a személyesen történố hálanyilvánítás az extrovertáltak esetében eredményesebbnek bizonyult, mint az introvertáltaknál (náluk ugyanilyen eredményes volt, ha telefonon vagy e-mail útján mondtak köszönetet). Újabban, Proyer, Wellenzohn, Gardner és Ruch (2015) egy három és fél évig tartó utánkövetéses vizsgálatban igazolták, hogy a személy-aktivitás illeszkedés a jóllétszint és a depresszió szintjének alakulása szempontjából is meghatározó. Konkrétan, a jóllétszint alakulása szempontjából lényegesnek találták, hogy (1) a személy folytatja-e a gyakorlást az intervenció befejezése után; (2) mekkora erôfeszítést tesz annak érdekében, hogy pontosan betartsa az alkalmazott intervenció instrukcióját; (3) a személy mennyire szimpatizál a gyakorlattal (preferencia); és milyen a gyakorlásra adott (4) korai reaktivitás. A depresszió szempontjából ugyanakkor csupán (1) a gyakorlás folytatása és a (2) korai re-

$8 \quad$ Például a testmozgáshoz vagy a mindfulnesshez kapcsolódó kutatásokat kihagyták. 
aktivitás bizonyult meghatározó tényezőnek. Az adatok felvetik annak a lehetôségét, hogy a programra adott korai pozitív érzelmi reaktivitás az egyik markere lehet annak, hogy a személy hosszabb távon is gyakorolni fogja-e a tanult intervenciót. Az azonban egyelőre nem tisztázott, hogy ez a korai érzelmi reaktivitás a személy-aktivitás jobb illeszkedésének jelzôje, vagy egy vonásszerú egyéni különbség, amely egyaránt megmutatkozik a különféle pozitív pszichológiai intervenciókban. Ezt a kérdést majd a jövóbeli kutatásoknak kell tesztelniük.

\section{DISZKUSSZIÓ}

A jelen tanulmány bemutatott néhány újabb kutatási eredményt a pozitív pszichológia elméleti hagyományaihoz és alkalmazási lehetôségeihez kapcsolódóan. Az elméleti fejezet a jóllét megközelítéseihez, mérési módszereihez, különbözô magyarázó modelljeihez és a pozitív érzelmek kutatásához kapcsolódóan kísérelte meg összefoglalni az újabb kutatások irányvonalait (pl. az egységesítô jóllétmodellek; a személyiség és a jóllét komplex összefüggései; a flow pszichogenetikai és neurobiológiai magyarázatai; egészséges pozitív érzelmek és optimális érzelmi egyensúly). Az alkalmazáshoz kapcsolódóan pedig a pozitív pszichológiai intervenciók hatékonyságához kapcsolódó kutatási eredményeket tekintettük át, és kritikai észrevételeket fogalmaztunk meg.

Hangsúlyoztuk, hogy annak ellenére, hogy a pozitív pszichológia jövôje szempontjából az irányzat által javasolt intervenciók hosszú távú hatásossága a kritikus kérdés, igazán hosszú távú követésbool származó eredmények egyelőre még nem állnak rendelkezésre, ezért a jövôben fontos lesz majd hosszabb időperiódusokra vonatkozólag is tesztelni ezeknek a módszereknek az eredményességét. A hatásvizsgálatokkal kapcsolatban korlátként említendô az is, hogy az eddigi kutatások tipikusan két vonatkozásban, a jóllétszint és a depresszió alakulása szempontjából vizsgálták az intervenciók hatékonyságát. Feltehetô azonban, hogy további előnyök is származhatnak ezekbôl az intervenciókból, úgymint az önértékelés növekedése, a jövedelem vagy a munkahelyi eredményesség fokozódása, vagy éppen a jobb egészségi állapot az immunfunkciók erôsödésén keresztül. Továbbá, a jövôben erôfeszítéseket célszerú tenni annak érdekében, hogy pontosabban megértsük a pozitív intervenciók hatékonyságának hátterében álló mechanizmusokat. Egyelôre megválaszolatlan kérdés az is, hogy a boldogságfokozó gyakorlatok mennyiben általánosíthatók a különbözô kultúrák között. Napjainkig a gyakorlatok hatásosságát ugyanis nagyrészt Észak-Amerikában tesztelték, és a hatásvizsgálatokban döntően egyetemisták vettek részt, vagy az általános populációból önkéntes alapon történt a mintagyújtés. Az utóbbi eljárással kapcsolatban torzító hatásként figyelembe kell venni, hogy a pozitív pszichológiai programokra önként jelentkezôk tipikusan középosztálybeli, és enyhén depressziós személyek, ôket foglalkoztatja ugyanis a boldogság témája a legintenzívebben. A jövôben ezért fontos lesz erôfeszítéseket tenni azért, hogy minél szélesebb rétegekhez jussanak el ezek a propagált pozitív gyakorlatok. Továbbá, jóval több randomizált, kontrollált kutatás szükséges ahhoz, hogy ne csak általánosságban tudjuk értékelni a pozitív pszichológiai intervenciók hatékonyságát, hanem az egyes gyakorlatok hatásosságára vonatkozóan külön-külön is végezni tudjunk metaelemzéseket. 


\section{IRODALOM}

Bolier, L., Haverman, M., Westerhof, G. J., Riper, H., Smit, F. \& Bohlmeijer, E. (2013). Positive psychology interventions: a meta-analysis of randomized controlled studies. BMC Public Health, 13(1), 1-20.

Costa, P. T. \& McCrae, R. R. (1988). Personality in adulthood: A six-year longitudinal study of self-reports and spouse ratings on the NEO Personality Inventory. Journal of Personality and Social Psychology, 54(2), 853-863.

Compton, W. C., Smith, M. L., Cornish, K. A. \& Qualls, D. L. (1996). Factor structure of mental health measures. Journal of Personality and Social Psychology, 71(2), 406-413.

Csíkszentmihályi, M. (1975). Beyond boredom and anxiety. Experiencing flow in work and play. San Francisco, CA: Jossey-Bass Publishers.

Dietrich, A. (2004). Neurocognitive mechanisms underlying the experience of flow. Consciousness and Cognition, 13(4), 746-761.

Diener, E., Suh, E. M., Lucas, R. E. \& Smith, H. L. (1999). Subjective well-being: Three decades of progress. Psychological Bulletin, 125(2), 276-302.

Diener, E. (1984). Subjective well-being. Psychological Bulletin, 95(3), 542-575.

Duckworth, A. L., Steen, T. A. \& Seligman, M. E. P. (2005). Positive psychology in clinical practice. Annual Review of Clinical Psychology, 1(1), 629-651.

Emmons, R. A. \& McCullough, M. E. (2003). Counting blessing versus burdens: An experimental investigation of gratitude and subjective well-being in daily life. Journal of Personality and Social Psychology, 84(2), 377-389.

Emmons, R. A. (1996). Striving and feelings: Personal goals and subjective well-being. In P. M. Gollwitzer, \& J. A. Bargh (Eds), The psychology of action: Linking cognition and motivation to behavior (pp. 313-337). New York: Guilford.

Fava, G. A. \& Ruini, C. (2003). Development and characteristics of a well-being enhancing psychotherapeutic strategy: Well-being therapy. Journal of Behavior Therapy and Experimental Psychiatry, 34(1), 45-63.

Fredrickson, B. L. (1998). What good are positive emotions? Review of General Psychology: Special Issue: New Directions in Research on Emotion, 2(3), 300-319.

Fredrickson, B. L. (2001). The role of positive emotions in positive psychology: The broadenand-build theory of positive emotions. American Psychologist, 56(3), 218-226.

Fredrickson, B. L. (2013). Love 2.0. New York: Hudson Street Press.

Gable, S. L., Reis, H. T., Impett, E., \& Asher, E. R. (2004). What do you do when things go right? The interpersonal and interpersonal benefits of sharing positive events. Journal of Personality and Social Psychology, 87(2), 228-245.

Gander, F., Proyer, R. T., Ruch, W. \& Wyss, T. (2013). Strength-based positive interventions: Further evidence for their potential in enhancing well-being and alleviating depression. Journal of Happiness Studies, 14(4), 1241-1259.

Gruber, J. \& Purcell, J. (2015). Positive emotion disturbance. In R. Scott \& S. Kosslyn (Eds), Emerging trends in the social and behavioral sciences (pp. 1-12). Hoboken: Wiley.

Gyurkovics, M., Kotyuk, E., Katonai, E. R., Horvath, E. Z., Vereczkei, A. \& Szekely, A. (2016). Individual differences in flow proneness are linked to a dopamine D2 receptor gene variant. Consciousness and Cognition, 42, 1-8. Letöltve: 2019. 07. 14. http://doi.org/10.1016/j. concog.2016.02.014

Huppert, F. A. \& So, T. T. C. (2013). Flourishing across Europe: Application of a new conceptual framework for defining well-being. Social Indicators Research, 110(3), 837-861.

Jose, P. E., Lim, B. T. \& Bryant, F. B. (2012). Does savoring increase happiness? A daily diary study. Journal of Positive Psychology, 7(3), 176-187. 
Keyes, C. L. (1998). Social well-being. Social Psychology Quarterly, 61(2), 121-140.

Lykken, D. \& Tellegen, A. (1996). Happiness is a stochastic phenomenon. Psychological Science, $7(3), 186-189$.

Lyubomirsky, S., Sheldon, K. M. \& Schkade, D. (2005). Pursuing happiness: The architecture of sustainable change. Review of General Psychology, 9(2), 111-131.

Lyubomirsky, S. (2008). Hogyan legyünk boldogok? Életünk átalakításának útjai tudományos megközelitésben. Budapest, Ursus Libris.

Lyubomirsky, S., King, L. A. \& Diener, E. (2005). The benefits and costs of frequent positive affect: Does happiness lead to success? Psychological Bulletin, 131(6), 803-855.

Magyaródi, T., \& Oláh, A. (2017). The Effect of Social Interaction on Flow Experience. International Journal of Psychology E Behavior Analysis, Open Access, 3(126), 1-5. http://doi. org/10.15344/2455-3867/2017/126

Nagy, H. (2019). A pozitíu pszichológia alkalmazása a klinikai és egészségpszichológiában. Budapest: ELTE Eötvös Kiadó.

Nagy H. \& Gyurkovics M. (2016). A pszichológiai jóllét szociodemográfiai korrelátumai, kapcsolata a Big Five vonásokkal és az optimizmussal. Mentálhigiéné és Pszichoszomatika, 17(3), 195-214.

Mosing, M. A., Magnusson, P. K. E., Pedersen, N. L., Nakamura, J., Madison, G. \& Ullén, F. (2012). Heritability of proneness for psychological flow experiences. Personality and Individual Differences, 53(5), 699-704.

Oláh, A. \& Nagy, H. (2014) (Eds). Flow, emotional intelligence and psychological immunity. Empirical Studies in Positive Psychology Perspective. Budapest: ELTE Eötvös Kiadó.

Oláh, A. (2012) (szerk.). A pozitív pszichológia világa. Budapest: Akadémiai Kiadó.

Peifer, C. (2012). Psychophysiological correlates of flow-experience. In S. Engeser (Ed.), Advances in Flow-Research (pp. 139-164). New York: Springer.

Peifer, C., Schulz, A., Schächinger, H., Baumann, N. \& Antoni, C. H. (2014). The relation of flow-experience and physiological arousal under stress - Can U shape it? Journal of Experimental Social Psychology, 53, 62-69.

Proyer, R. T., Wellenzohn, S., Gander, F. \& Ruch, W. (2015). Toward a better understanding of what makes positive psychology interventions work: Predicting happiness and depression from the person $\times$ intervention fit in a follow-up after 3,5 years. Applied Psychology. Health and Well-being, 7(1), 108-128.

Ryff, C. D. (2014). Psychological well-being revisited: Advances in the science and practice of eudaimonia. Psychotherapy and Psychosomatics, 83(1), 10-28.

Ryff, C. D. (1989). Happiness is everything, or is it? Explorations on the meaning of psychological well-being. Journal of Personality and Social Psychology, 57(6), 1069-1081.

Salzburg, S. (2011). Real happiness: The power of meditation. New York: Workman Publishing.

Schuller, S. M. (2012). Personality fit and positive interventions: Extraverted and introverted individuals benefit from different happiness increasing strategies. Psychology, 3(12-A), 11661173.

Seligman, M. E. P., Rashid, T. \& Parks, A. C. (2006). Positive psychotherapy. American Psychologist, 61(8), 774-788.

Seligman, M. E. P., Steen, T. A., Park, N. \& Peterson, C. (2005). Positive psychology progress: Empirical validation of interventions. American Psychologist, 60(5), 410-421.

Seligman, M. E. P. \& Csíkszentmihályi, M. (2000). Positive psychology: An introduction. American Psychologist, 55(1), 5-14.

Sin, N. L. \& Lyubomirsky, S. (2009). Enhancing well-being and alleviating depressive symptoms with positive psychology interventions: A practice-friendly meta-analysis. Journal of Clinical Psychology: In Session, 65(5), 467-487. 
Sin, N. L., Della Porta, M. D. \& Lyubomirsky, S. (2011). Tailoring positive psychology interventions to treat depressed individuals. In S. I. Donaldson, M. Csíkszentmihályi \& J. Nakamura (Eds), Applied positive psychology: Improving everyday life, health, schools, work and society (pp. 79-96). New York: Routledge.

Snyder, C. R. (1994). The psychology of hope: You can get there from here. New York: Free Press.

Soltész, P., Magyaródi, T., Mózes, T., Nagy, H. \& Oláh, A. (2012). A flow élmény elektrofiziológiája. Magyar Pszichológiai Szemle, 67(1), 77-103.

Soto, C. J. (2015). Is happiness good for your personality? Concurrent and prospective relations of the Big Five with Subjective well-being. Journal of Personality, 83(1), 45-55.

Tellegen, A., Lykken, D. T., Bouchard, T. J., Wilcox, K. J., Segal, N. S. \& Rich, S. (1988). Personality similarity in twins reared apart and together. Journal of Personality and Social Psychology, 54(6), 1031-1039.

Ulrich, M., Keller, J., Hoenig, K., Waller, C. \& Grön, G. (2014). Neural correlates of experimentally induced flow experiences. Neuroimage, 86, 194-202.

Weiss, L. A., Westerhof, G. J. \& Bohlmeijer, E. T. (2016). Can we increase psychological wellbeing? The effects of interventions on psychological well-being: A meta-analysis of Randomized Controlled Trials. PLoS One, 11(6), e0158092.

\section{POSITIVE PSYCHOLOGY: FROM THE THEORY TO THE PRACTICE}

\section{NAGY, HENRIETT}

Positive psychology, - which is a scientific approach aiming to comprehend well-being (Seligman $\mathcal{E}$ Csikszentmihályi, 2000) - during the last two decades has become very popular all over the world. In Hungary, the first introduction of research in positive psychology was in a special edition of the Hungarian Review of Psychology (Magyar Pszichologiai Szemle), which was edited by Attila Oláh in 2012. The present study makes an attempt to give an insight into some important results, which have been published since the publication of the above-mentioned special edition (e.g., integrated well-being models; complex connections between personality and well-being; the psychogenetic and neurobiological basis of the flow; healthy positive emotions; optimal affective balance), and provides some critical comments regarding the future of the approach, primarily concentrating on the effectiveness of positive psychology interventions.

Keywords: positive psychology, well-being, positive emotions, positive psychology interventions

A cikk a Creative Commons Attribution 4.0 International License (https://creativecommons. org/licenses/by/4.0) feltételei szerint publikált Open Access közlemény, melynek szellemében a cikk bármilyen médiumban szabadon felhasználható, megosztható és újraközölhetô, feltéve, hogy az eredeti szerzó és a közlés helye, illetve a CC License linkje és az esetlegesen végrehajtott módosítások feltüntetésre kerülnek. (SID_1) 